\title{
Computer Literacy and Attitudes towards eLearning among Sri Lankan Medical Students
}

\author{
Dr. Y. M. M. M. Yapa MBBS, MSc \\ Ministry of Health, Colombo, Sri Lanka \\ E-Mail address: mayurayapa@ gmail.com \\ Dr. M. M. N. S. Dilan MBBS, MSc \\ Ministry of Health, Colombo, Sri Lanka \\ E-Mail address: mmnsdilan@gmail.com
}

Dr. W. C. D. Karunaratne MBBS, MSc

Ministry of Health, Colombo, Sri Lanka

E-Mail address: dilminikarunaratne@gmail.com

Dr. C. C. Widisinghe MBBS, MSc

Ministry of Health, Colombo, Sri Lanka

E-Mail address: chrishanwc@gmail.com

Dr. Roshan Hewapathirana MBBS, MSc

Department of Informatics, Faculty of Mathematics and Natural Sciences, University of Oslo, Norway

E-Mail address: roshanhewapathirana@gmail.com

Dr. Indika Karunathilake MBBS, MMedEd, CTHE

Director-MEDARC, Faculty of Medicine, University of Colombo, Sri Lanka

E-Mail address: karunathilake@ hotmail.com

Sri Lanka Journal of Bio-Medical Informatics 2012;3(3):82-96

doi: http://dx.doi.org/10.4038/sljbmi.v3i3.3719

\begin{abstract}
E-learning which is gaining popularity among medical faculties in Sri Lanka requires access to computers and considerable knowledge on information technology. The aim of this study was to assess the computer literacy and attitudes towards e-learning among second year medical students of the Faculty of Medicine, Colombo (n=138) using a self administered, anonymous questionnaire.

Results showed that $93.5 \%$ of students owned a computer and $95 \%$ of them had internet connection. Use of Microsoft Office ${ }^{\circledR}$ applications was high (90\%), along with online communication tools (73.5\%). Using ICT for educational purposes was low (51.7\%). Use of popular Web 2.0 tools such as Facebook (89.1\%), Wikipedia $(87.6 \%)$, and YouTube (74.4\%) was high. There was a significant difference between gender in the use of blogs $(\mathrm{P}<0.01)$, and Twitter $(\mathrm{P}<0.01)$ with male students using these more. Majority of students $(65.7 \%)$ spent less time on their computer for learning purposes.

Commonly accessed online learning materials were text $(82.3 \%)$ and images $(81.7 \%)$. Advantages of online learning materials have been recorded as being more accessible $(89.5 \%)$, descriptive $(85.7 \%)$ and easily searchable $(88.1 \%)$.

Awareness of the faculty Moodle platform was low among students (65.7\%), as well as usage (32.7\%) and 94.7\% of students preferred supplementary learning material to be incorporated in the Moodle platform.
\end{abstract}


This study shows that medical students have access to computers and other facilities required for e-learning and a positive attitude towards e-learning. However, the use of computers for learning purposes was low. This highlights the need for guidance on the use of available resources for e-learning.

Keywords - e-Learning; Computer Usage; Learning Management Systems; Social Media; Internet Access

\section{Introduction}

Training medical students can be time consuming and strenuous. To the modern medical student learning in the form of traditional teaching via lectures and referencing paper based publications is difficult. Medical educationists have identified e-learning as an effective way of delivering medical education $^{(1)}$.

E-learning comprises of all forms of electronically supported learning and teaching ${ }^{(2)}$. Information and communication systems supplements the learning process. Learning Management Systems (LMS) are used as the e-learning platform to conduct medical education in an interactive and exciting manner.

Current uses of information technology in medical education with regard to e-learning include, Computer Assisted Learning (CAL), Online learning platforms/Distance Education, Instructional Material Designing (IMD), Online journals, Simulations, and Teleconferencing etc. ${ }^{(3)}$.

Medical education institutes such as The International Virtual Medical School (IVIMEDS) based in Dundee, U K has already tried using e-learning as a stand-alone solution ${ }^{(4)}$. Some institutions are using e-learning as a part of their blended curricula in which e-learning is playing a role of supplementing or as an adjunct tool ${ }^{(5)}$.

Due to the impact of IT in medical education, computer literacy and e-learning among medical students have become a popular topic among researchers around the world. Having a sound knowledge in Information and Communication Technology is an emerging requirement in both undergraduate and postgraduate level because of its significant impact on learning. The Medical Faculty of the University of Colombo recently established an online learning platform for their students. It is based on Moodle which is an open source learning management system ${ }^{(6)}$. Content is currently being created and uploaded to it.

This cross-sectional descriptive study with an analytical component was conducted to assess the computer knowledge, computer usage and attitudes towards e-learning among medical students of the Faculty. This will help to identify the needs of the students in relation to application of technology for education. Thereafter the content which is being created can be catered to the students' needs, leading to a better learning experience. This will lead to the establishment of elearning as an adjunct tool to face to face learning, which is the current trend in medical education globally. There is evidence for the effectiveness and acceptance of e-learning within the medical education community, especially when combined with traditional teacher-led activities in a blended 
learning educational experience ${ }^{(7)}$. The integration of e-learning into medical education can catalyse the shift toward applying adult learning theory, where teachers will no longer serve as the distributors of content, but will become more involved as facilitators of learning and assessors of competency.

Objectives of this study were:

- To assess the availability and usage of computers and internet among medical students.

- To evaluate perceived competency in using basic software applications and online educational tools.

- To determine the attitude of medical students towards e-learning.

- To identify the difficulties faced by students in using e-learning tools.

\section{Methods}

Study population consisted of second year medical students of the Faculty of Medicine, Colombo of Colombo. There were 193 students in the batch, consisting of 101 male students and 92 female students.

A Self administered anonymous questionnaire was used after initial validation (pre testing) conducted on 20 medical students. In order to make the students comfortable with the questions, the questionnaire was formulated in the 'first person' and simple English was used. The answers were on a 'Multiple Choice Question' (MCQ) basis. 'Likert Scale' ${ }^{\text {(7) }}$ was used when possible to decrease the number of mixed responses. The questionnaire included information on Computer literacy, computer accessibility, internet facilities, participation in social media/web 2.0, computer usage for learning, accessing exposure to an online learning platform, competency in using Moodle, and learning preferences.

The questionnaires were distributed at the end of a lecture after a brief introduction of the study. Research members were available for any questions or clarifications. Results were entered into the PASW statistical software package (Version 18) and analysis was done. Chi square test was used to compare between identified variables with $\mathrm{X}^{2}>7.82(\mathrm{P}<0.05)$ or $\mathrm{X}^{2}>11.34(\mathrm{P}<0.01)$ being taken as statistically significant when degree of freedom $(\mathrm{df})=3$, and $\mathrm{X}^{2}>5.99(\mathrm{P}<0.05)$ or $\mathrm{X}^{2}>9.21(\mathrm{P}<0.01)$ was taken as statistically significant when $\mathrm{df}=2$.

\section{Results}

The second year batch has 193 medical students but only 153 were present at the time of study. The number of respondents to the questionnaire was 138. The gender distributions among the respondents were 70 Male, and 68 female. The study therefore has a 90\% CI with less than 3.8\% error margin with no bias in terms of gender, as the respondent population nearly had the same ratio $(1: 1)$ as the total population $(1.09: 1)$.

About $93.5 \%$ of the students owned a computer. Out of them, some owned a desktop (43.1\%), or 
a laptop $(31.8 \%)$, or both $(24.1 \%)$. Out of the students who owned a computer, $95 \%$ had an internet connection at home. The remaining $6.5 \%$ of students also had access to a computer through a friend or the CAL lab (Computer Aided Learning Laboratory). $67 \%$ of them had access to the internet. It may be noted that as the CAL lab of the Faculty has internet connectivity, and access is given to students during work hours, coverage could be taken as $100 \%$ for internet. Therefore, it can be assumed that tools necessary for e-learning are readily available with the students.

\begin{tabular}{|c|c|c|c|c|}
\hline & $\%$ & $\begin{array}{l}\text { Less than } 6 \\
\text { months }\end{array}$ & $\begin{array}{l}6 \text { months } \\
\text { to } 2 \text { years }\end{array}$ & $\begin{array}{c}\text { More than } \\
2 \text { years } \\
\end{array}$ \\
\hline \multirow[t]{3}{*}{ Microsoft Office $^{\circledR}$ Applications } & Male & 2.3 & 2.3 & 44.6 \\
\hline & Female & 0.8 & 4.6 & 45.4 \\
\hline & Total & 3.1 & 6.9 & 90.0 \\
\hline \multirow[t]{3}{*}{ Communication tools } & Male & 1.5 & 8.1 & 40.4 \\
\hline & Female & 1.5 & 15.4 & 33.1 \\
\hline & Total & 3.0 & 23.5 & 73.5 \\
\hline \multirow[t]{3}{*}{ Educational tools } & Male & 3.0 & 14.3 & 32.4 \\
\hline & Female & 3.0 & 18.0 & 29.3 \\
\hline & Total & 6.0 & 32.3 & 51.7 \\
\hline
\end{tabular}

Table 1. The duration of use of applications

Duration of use of applications by the students was assessed in the form of Microsoft Office ${ }^{\circledR}$ applications, communication tools and educational tools (Table 1). Usage of Microsoft applications was very high while $90 \%$ of users having been using the application for more than two years. Usage of communication modes such as e-mail and skype was also very good, with $73.5 \%$ of students using these for more than two years. However, usage of educational resources and applications was significantly lower with only $51.7 \%$ using them for more than two years.

\begin{tabular}{|l|l|c|c|c|c|}
\hline & & \multicolumn{4}{|c|}{ Perceived Competency (\%) } \\
\hline & & None & Basic & Average & Power User \\
\hline \multirow{3}{*}{ Microsoft Word $^{\circledR}$} & Male & 2.2 & 8.7 & 33.3 & 6.5 \\
\cline { 2 - 6 } & Female & 0.0 & 8.0 & 32.6 & 8.7 \\
\cline { 2 - 6 } & Total & 2.2 & 16.7 & 65.9 & 15.2 \\
\hline \multirow{2}{*}{ Microsoft Excel $^{\circledR}$} & Male & 1.4 & 10.1 & 33.3 & 5.8 \\
\cline { 2 - 6 } & Female & 0.0 & 8.0 & 32.6 & 8.7 \\
\cline { 2 - 6 } & Total & 1.4 & 18.1 & 65.9 & 14.5 \\
\hline Microsoft PowerPoint $^{\circledR}$ & Male & 3.6 & 25.5 & 19.0 & 2.2 \\
\cline { 2 - 6 } & Female & 3.6 & 21.2 & 22.6 & 2.2 \\
\cline { 2 - 6 } & Total & 7.2 & 46.7 & 41.6 & 4.4 \\
\hline
\end{tabular}

Table 2. Perceived competency in Microsoft Office ${ }^{\circledR}$ applications 
Students perceived competency in Microsoft Office ${ }^{\circledR}$ applications did not show any major disparity according to gender (Table 2). It can be seen clearly that students perceive themselves to be competent in Microsoft Word ${ }^{\circledR}$ and Excel ${ }^{\circledR}$, but did not have the same competency in Microsoft PowerPoint ${ }^{\circledR}$. Students' proficiency in communication applications was found to be very good (Table 3). 93\% of students labeled themselves average or above in internet browsing. This was also high for e-mail competency ( $89 \%$ average or above). However, in using online communication applications such as skype or yahoo messenger, only $62.7 \%$ students were competent. Therefore, there is a need to enhance the use of these methods among students as online communication is a very important aspect of e-learning. Competency in using online educational tools among medical students was found to be significantly less than using other online tools (Table 4). Only 37.2\% of students perceived themselves competent (average or above) in using online forums such as Medhelp for their learning purposes. This was the same for Online Journals/Databases (42.4\%- average or above), and Learning Management Systems (26.3\%- average or above). However, students were feeling more competent in using educational websites such as Wikipedia and WebMD for their learning purposes (75.4\%-average or above).

\begin{tabular}{|l|l|c|c|c|c|}
\hline & & \multicolumn{4}{|c|}{ Perceived Competency \% } \\
\hline \multirow{4}{*}{ Internet Browsing } & & None & Basic & Average & Power User \\
\hline \multirow{4}{*}{ E-mail } & Male & 0.7 & 3.6 & 24.8 & 21.9 \\
\cline { 2 - 6 } & Female & 0.0 & 2.2 & 25.5 & 21.2 \\
\cline { 2 - 6 } & Total & 0.7 & 5.8 & 50.3 & 43.1 \\
\hline \multirow{5}{*}{ Online Communication } & Male & 3.6 & 29.9 & 16.1 & 1.5 \\
\cline { 2 - 6 } & Female & 5.8 & 26.3 & 16.8 & 0.0 \\
\cline { 2 - 6 } & Total & 9.4 & 56.2 & 32.9 & 1.5 \\
\hline & Male & 11.7 & 18.2 & 15.3 & 9.5 \\
\cline { 2 - 6 } & Female & 7.3 & 16.1 & 13.1 & 8.8 \\
\cline { 2 - 6 } & Total & 19.0 & 34.3 & 28.4 & 18.3 \\
\hline
\end{tabular}

Table 3. Perceived competency in web based communication applications

As identified, using learning management systems was the weakest method in student's online learning (37.2\% -no competency). This has to be addressed immediately as learning management systems are one of the leading tools of online education which delivers multimedia enriched content that stimulates higher and deep learning. Addressing this problem also becomes critical as the learning materials currently being developed for them will be uploaded to the Moodle platform of the Faculty and to get the maximum benefit they must be comfortable and competent in using it. At first glance, there seems to be a slight gender bias, with males showing slightly better competency in using educational tools. However difference was not statistically significant for any of the educational tools.

The students were equally divided among themselves with regard to need of training (Table 5) on Microsoft Office ${ }^{\circledR}$ applications (48.1\% Positive), and use of online communication tools such as e-mail, Skype (51.9\% Positive). Therefore when conducting a training course for them, it 
would be in the best interest of the students to make it optional, so that the students who are competent can opt out. However, a screening test could be done to confirm the competency of the students, before allowing them to opt out. The need for training on the use of online educational resources such as medical forums, medical journals, learning management systems (e.g. Moodle) has been identified by the students themselves ( $87 \%$ - positive responses). This is an important aspect of e-learning, and therefore when conducting such training, participation should be mandatory. There was a need to assess if there is a statistical significant difference among the stated competencies in relevant fields, and the need for further training as stated by the students. The majority of students prefer to have training before the start of academic activities, when they have just gained entrance to the Faculty (Figure 1). Such training will allow the students to gain knowledge and skills in the required application, at a very early stage, and therefore they can start using the applications during their degree course without any hindrance to academic work.

\begin{tabular}{|l|l|c|c|c|c|}
\hline & & \multicolumn{4}{|c|}{ Perceived Competency (\%) } \\
\hline & & None & Basic & Average & Power User \\
\hline \multirow{2}{*}{$\begin{array}{l}\text { Online Forums } \\
\text { (eg. Medhelp) }\end{array}$} & Male & 14.0 & 13.2 & 19.9 & 3.6 \\
\cline { 2 - 6 } & Female & 14.7 & 19.9 & 12.5 & 2.2 \\
\cline { 2 - 6 } & Total & 28.7 & 33.1 & 32.4 & 5.8 \\
\hline \multirow{2}{*}{$\begin{array}{l}\text { Online Journals \& } \\
\text { Data Bases }\end{array}$} & Male & 8.0 & 19.0 & 19.7 & 3.6 \\
\cline { 2 - 6 } & Female & 8.0 & 22.6 & 16.1 & 3.0 \\
\cline { 2 - 6 } & Total & 16.0 & 41.6 & 35.8 & 6.6 \\
\hline \multirow{2}{*}{$\begin{array}{l}\text { Learning Management } \\
\text { Systems Moodle) }\end{array}$} & Male & 18.2 & 16.1 & 14.6 & 1.5 \\
\cline { 2 - 6 } & Female & 19.0 & 20.4 & 9.5 & 0.7 \\
\cline { 2 - 6 } & Total & 37.2 & 36.5 & 24.1 & 2.2 \\
\hline
\end{tabular}

Table 4. Perceived competency in online educational resources

\begin{tabular}{|l|l|c|c|}
\hline & & \multicolumn{2}{|c|}{ Need for Training \% } \\
\hline \multirow{3}{*}{ Use of Microsoft Office ${ }^{\circledR}$ Applications } & & Yes & No \\
\hline \multirow{3}{*}{ Use of Online Communication Tools } & Male & 25.5 & 24.8 \\
\cline { 2 - 4 } & Female & 22.6 & 27.1 \\
\cline { 2 - 4 } & Total & 48.1 & 51.9 \\
\hline \multirow{3}{*}{ Use of Online Educational Tools } & Male & 24.8 & 25.5 \\
\cline { 2 - 4 } & Female & 27.1 & 22.6 \\
\cline { 2 - 4 } & Total & 51.9 & 48.1 \\
\hline & Male & 42.1 & 8.7 \\
\cline { 2 - 4 } & Female & 44.9 & 4.3 \\
\cline { 2 - 4 } & Total & 87.0 & 13.0 \\
\hline
\end{tabular}

Table 5. Perceived need for training in applications 

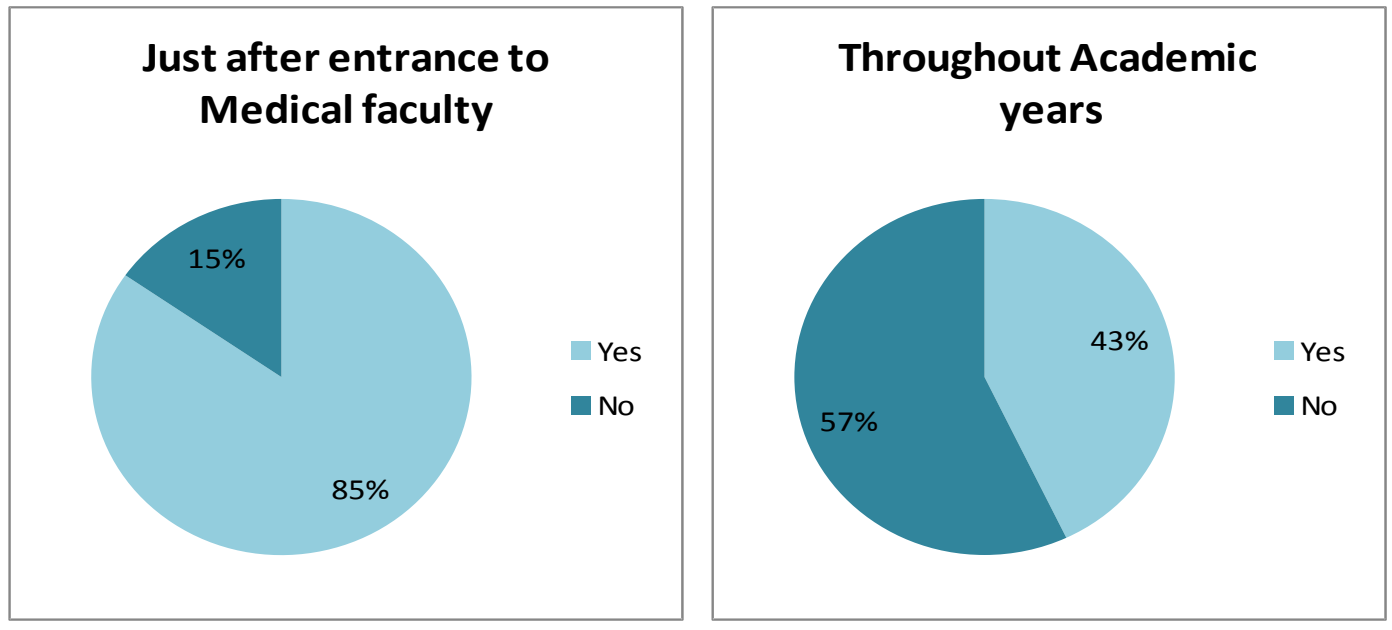

Figure 1. Preference in receiving training in Internet and Communications Technology

\section{Participation in social media/web 2.0}

The term Web 2.0 is associated with web applications that facilitate participatory information sharing, interoperability, user-centered design, and collaboration on the World Wide Web. A Web 2.0 site allows students to interact and collaborate with each other in a social media dialogue as creators (prosumers) of user-generated content in a virtual community ${ }^{(9)}$. It is important to identify the current level of exposure to web 2.0 among medical students.

\begin{tabular}{|c|c|c|c|c|}
\hline & & \multicolumn{3}{|c|}{ Participation Level \% } \\
\hline & & Frequently & Occasionally & Never \\
\hline \multirow{3}{*}{$\begin{array}{l}\text { Blogs } \\
\text { (eg. BlogSpot) }\end{array}$} & Male & 7.3 & 22.6 & 21.2 \\
\hline & Female & 2.9 & 12.4 & 33.6 \\
\hline & Total & 10.2 & 37.0 & 55.8 \\
\hline \multirow{3}{*}{$\begin{array}{l}\text { Social Networks } \\
\text { (eg. Facebook) }\end{array}$} & Male & 32.6 & 13.8 & 4.3 \\
\hline & Female & 30.4 & 12.3 & 6.6 \\
\hline & Total & 63.0 & 26.1 & 10.9 \\
\hline \multirow{3}{*}{$\begin{array}{l}\text { Micro blogging } \\
\text { (eg. Twitter) }\end{array}$} & Male & 4.5 & 14.9 & 31.3 \\
\hline & Female & 0.7 & 6.0 & 42.6 \\
\hline & Total & 5.2 & 20.9 & 73.9 \\
\hline \multirow{3}{*}{$\begin{array}{l}\text { Virtual Reality } \\
\text { (eg. Second life) }\end{array}$} & Male & 2.3 & 13.0 & 35.1 \\
\hline & Female & 0.8 & 6.9 & 42.0 \\
\hline & Total & 3.1 & 19.9 & 77.1 \\
\hline
\end{tabular}

Table 6. Level of participation in Web 2.0 social communication media 
Due to the immense popularity of social networking sites such as facebook, the participation level (Table 6) was very high $(89.1 \%)$. However, the participation levels dropped to $47.2 \%$ for blogging, $26.1 \%$ for micro blogging and $23 \%$ for virtual reality (e.g. second life). Blog participation is more fruitful in the e-learning than social networks or micro blogging. Virtual reality can lead to more immersive learning experiences. Second life is currently being used around the world to conduct online interactive classes. Also many leading universities have their own 'second life' like platforms ${ }^{(10)}$. Therefore, there is a need to encourage students to create and participate in blogs, as well as virtual reality sites such as second life.

While there was no gender gap in social networking participation, statistically significant gender disparity (using chi square tests) was seen in the use of blogs, $\left(\chi^{2}=10.4, p<0.01\right.$ ), and also micro blogging $\left(\chi^{2}=10.96, \mathrm{p}<0.01\right)$ where male students were more involved than female students. Even though there was more participation in virtual reality sites by male students, it was not statistically significant.

The student participation in wikis as a collaborative tool is very good, with only $12.4 \%$ not participating (Table 7). It was significantly lower with regard to document managing and editing tools (50.9\% - not participating). There was no statistical difference between genders with regard to both methods. Wikis are a very good method of e-learning, and this was mainly due to the popularity of Wikipedia, where people can access information, edit and collaborate with others on any topic. Video sharing (eg. YouTube) was the most common method of multimedia sharing (74.4\%) (Table 8).

\begin{tabular}{|c|c|c|c|c|}
\hline & & \multicolumn{3}{|c|}{ Participation Level \% } \\
\hline & & Frequently & Occasionally & Never \\
\hline \multirow{3}{*}{$\begin{array}{l}\text { Wikis } \\
\text { (eg. Wikipedia) }\end{array}$} & Male & 24.1 & 21.2 & 5.8 \\
\hline & Female & 24.8 & 17.5 & 6.6 \\
\hline & Total & 48.9 & 38.7 & 12.4 \\
\hline \multirow{3}{*}{$\begin{array}{l}\text { Document managing and editing } \\
\text { tools } \\
\text { (eg. Google docs) }\end{array}$} & Male & 8.9 & 20.0 & 22.2 \\
\hline & Female & 8.9 & 13.3 & 26.7 \\
\hline & Total & 17.8 & 33.3 & 50.9 \\
\hline
\end{tabular}

Table 7. Level of participation in Web 2.0 collaboration

However, image sharing was low with $55.9 \%$ students not using it, and presentation sharing even less with $73.8 \%$ of students not using it. There was no statistical difference between males and females. During this study, we could only assess participation to a limited number of Web 2.0 tools which were commonly used, as well as important for e-learning purposes. It may be noted that there are more Web 2.0 tools in the World Wide Web (WWW). 
According to the students, the time they spent on their computers for learning purposes was very low, with the majority (65.7\%) using it for less than an hour (Table 9). However, the time spent by female students for learning purposes on their computer was more than that spent by male students $\left(\chi^{2}=7.530, \mathrm{P}<0.05\right)$.

\begin{tabular}{|c|c|c|c|c|}
\hline & & \multicolumn{3}{|c|}{ Participation Level \% } \\
\hline & & Frequently & Occasionally & Never \\
\hline \multirow{3}{*}{$\begin{array}{l}\text { Image Sharing } \\
\text { (eg. Flickr) }\end{array}$} & Male & 2.9 & 22.6 & 25.5 \\
\hline & Female & 4.4 & 13.1 & 31.4 \\
\hline & Total & 7.3 & 35.7 & 55.9 \\
\hline \multirow{3}{*}{$\begin{array}{l}\text { Video Sharing } \\
\text { (eg. Youtube) }\end{array}$} & Male & 18.2 & 19.0 & 13.9 \\
\hline & Female & 17.5 & 19.7 & 11.7 \\
\hline & Total & 35.7 & 38.7 & 25.6 \\
\hline \multirow{3}{*}{$\begin{array}{l}\text { Presentation Sharing } \\
\text { (eg. Slideshare) }\end{array}$} & Male & 0.7 & 14.6 & 35.8 \\
\hline & Female & 2.2 & 8.8 & 38.0 \\
\hline & Total & 2.9 & 23.4 & 73.8 \\
\hline \multirow{3}{*}{$\begin{array}{l}\text { Livecasting } \\
\text { (eg. Skype) }\end{array}$} & Male & 9.0 & 21.6 & 20.2 \\
\hline & Female & 11.9 & 14.9 & 22.4 \\
\hline & Total & 20.9 & 36.5 & 42.6 \\
\hline
\end{tabular}

Table 8. Level of participation in Web 2.0 multimedia sharing

\begin{tabular}{|l|c|c|c|}
\hline & \multicolumn{3}{|c|}{ Time Duration (\%) } \\
\hline & $\begin{array}{c}\text { Less } \\
\text { than1 } \\
\text { hour }\end{array}$ & $\begin{array}{c}\text { 1 to 3 } \\
\text { Hours }\end{array}$ & $\begin{array}{c}\text { More than 3 } \\
\text { Hours }\end{array}$ \\
\hline Male & 37.3 & 10.4 & 3.0 \\
\hline Female & 28.4 & 20.1 & 0.8 \\
\hline Total & 65.7 & 30.5 & 3.8 \\
\hline
\end{tabular}

Table 9. Daily use of computers for learning purposes

Out of the three office applications (Table 10), PowerPoint (76.3) was the most used and Excel was the least used (27.2\%). However, according to the previous data, students' knowledge on PowerPoint was the lowest. Therefore, there is a need to improve PowerPoint skills among students. The Table 11 shows that there was a healthy use of online resources by medical students to enhance their learning. The use of online resources increases with the complexity of the subject. Text was the most common type of supplementary learning material (Table 12) accessed by the students ( $82.3 \%$ mostly/sometimes). Online images $(81.7 \%)$ took second place. 
These are also the main types of supplementary material that are commonly available to students. Video and audio clips are also sought by medical students as supplementary material. The low use of interactive clinical scenarios/virtual patients may be due to the fact that there are only a few resources currently available on the web. There was no statistical difference in usage between males and females.

\begin{tabular}{|l|l|c|c|}
\hline & & \multicolumn{2}{|c|}{$\begin{array}{c}\text { Use for learning } \\
\text { purposes \% }\end{array}$} \\
\hline \multirow{3}{*}{ Microsoft Office Word $^{\circledR}$} & & Yes & No \\
\hline \multirow{3}{*}{ Microsoft Office Excel $^{\circledR}$} & Male & 21.9 & 24.8 \\
\cline { 2 - 4 } & Female & 24.1 & 29.2 \\
\cline { 2 - 4 } & Total & 56.0 & 44.0 \\
\hline \multirow{3}{*}{ Microsoft Office PowerPoint $^{\circledR}$} & Male & 11.8 & 39.7 \\
\cline { 2 - 4 } & Female & 15.4 & 33.1 \\
\cline { 2 - 4 } & Total & 27.2 & 72.8 \\
\cline { 2 - 4 } & Male & 34.8 & 16.3 \\
\cline { 2 - 4 } & Female & 41.5 & 7.4 \\
\cline { 2 - 4 } & Total & 76.3 & 23.7 \\
\hline
\end{tabular}

Table 10. Use of Microsoft applications for learning purposes

\begin{tabular}{|l|l|c|c|c|c|}
\hline & & \multicolumn{4}{|c|}{ Use of Online Resources \% } \\
\hline \multirow{2}{*}{$\begin{array}{l}\text { Many Topics taught in } \\
\text { the Faculty }\end{array}$} & & Mostly & Sometimes & Rarely & Never \\
\cline { 2 - 6 } & Female & 10.0 & 23.8 & 13.1 & 5.4 \\
\cline { 2 - 6 } & Total & 17.7 & 48.4 & 23.1 & 10.8 \\
\hline \multirow{2}{*}{$\begin{array}{l}\text { Some Topics taught in } \\
\text { the Faculty }\end{array}$} & Male & 7.4 & 27.3 & 11.6 & 5.8 \\
\cline { 2 - 6 } & Female & 8.3 & 33.1 & 4.1 & 2.5 \\
\cline { 2 - 6 } & Total & 15.7 & 60.4 & 15.7 & 8.3 \\
\hline \multirow{2}{*}{$\begin{array}{l}\text { Difficult topics taught in } \\
\text { the Faculty }\end{array}$} & Male & 21.0 & 21.8 & 6.7 & 4.2 \\
\cline { 2 - 6 } & Female & 17.6 & 21.8 & 5.9 & 0.8 \\
\cline { 2 - 6 } & Total & 38.6 & 43.6 & 12.6 & 5.0 \\
\hline \multirow{2}{*}{$\begin{array}{l}\text { Many Topics taught in } \\
\text { the Faculty }\end{array}$} & Male & 10.0 & 23.8 & 13.1 & 5.4 \\
\hline \multirow{4}{*}{} & & & & & \\
\hline & Female & 7.7 & 24.6 & 10.0 & 5.4 \\
\cline { 2 - 6 } & Total & 17.7 & 48.4 & 23.1 & 10.8 \\
\hline
\end{tabular}

Table 11. Types of topics that students use online resources for learning purposes 
The five main positive attributes that have been identified by the students with regard to online resources are in Table 13. The students' approval of online learning was therefore quite apparent. However, some negative points have also been identified as shown below:

The negative aspects mentioned in table 14 do not qualify directly to be a failure of online resources. For instance the reason that the computer screen is hard to read maybe that the students are using CRT monitors. However, the newer LCD, LED monitors do not have this problem. Also as the current syllabus of the Medical Faculty is mainly paper-based, there is not much time allocated to access the internet or Faculty Moodle during working hours. But students do have access to the Faculty Moodle through internet at anytime.

In the Faculty of Medicine, Colombo, access is given to all the students from the second academic year onwards. However, as the Moodle platform was made online only recently, and content is still being created and uploaded, awareness among students (Table 15) with regard to the Faculty Moodle platform was still low (65.9\%), but is expected to increase by the end of this year, and should reach $100 \%$. Due to the fact that content was scarce at the beginning of this year; students did not frequently use the Moodle platform. However, with the increasing amount of content that is being uploaded, medical students will be encouraged to use the Moodle platform.

\begin{tabular}{|l|l|c|c|c|c|}
\hline & & \multicolumn{4}{|c|}{ Use of Online Resources } \\
\hline & & Mostly & Sometimes & Rarely & Never \\
\hline \multirow{4}{*}{ Reading/Text materials } & Male & 21.3 & 21.3 & 5.9 & 2.2 \\
\cline { 2 - 6 } & Female & 19.1 & 20.6 & 6.6 & 2.9 \\
\cline { 2 - 6 } & Total & 40.4 & 41.9 & 12.5 & 5.1 \\
\hline \multirow{4}{*}{ Videos /Animations } & Male & 10.1 & 25.4 & 10.9 & 4.3 \\
\cline { 2 - 6 } & Female & 8.0 & 26.1 & 12.3 & 2.9 \\
\cline { 2 - 6 } & Total & 18.1 & 51.5 & 23.2 & 7.2 \\
\hline \multirow{5}{*}{ Audio Clips } & Male & 5.9 & 18.4 & 17.6 & 8.8 \\
\cline { 2 - 6 } & Female & 4.4 & 22.1 & 17.7 & 5.1 \\
\cline { 2 - 6 } & Total & 10.3 & 40.5 & 35.3 & 13.9 \\
\hline \multirow{3}{*}{ Onteractive Clinical Scenarios/ } & Male & 14.7 & 24.3 & 8.8 & 2.2 \\
\cline { 2 - 6 } & Female & 16.2 & 26.5 & 5.9 & 1.5 \\
\cline { 2 - 6 } & Total & 30.9 & 50.8 & 14.7 & 3.7 \\
\cline { 2 - 6 } & Male & 4.5 & 12.0 & 16.5 & 18.8 \\
\cline { 2 - 6 } & Female & 4.5 & 11.3 & 15.8 & 16.5 \\
\cline { 2 - 6 } & Total & 9.0 & 23.2 & 32.3 & 35.3 \\
\hline
\end{tabular}

Table 12. Supplementary online resource materials currently accessed

93.5\% of the Faculty Moodle platform users found the content to be useful, and $96.7 \%$ requested that more content be made available. It shows that the Moodle platform was successful in 
providing supplementary learning material to the medical students, and it had stimulated learning.

\begin{tabular}{|l|c|c|}
\hline \multirow{2}{*}{$\begin{array}{c}\text { Positive Qualities of Online } \\
\text { Resources }\end{array}$} & \multicolumn{2}{|c|}{ Preference (\%) } \\
\cline { 2 - 3 } & Yes & No \\
\hline Accessed anytime anywhere & 89.5 & 10.5 \\
\hline More descriptive & 85.7 & 14.3 \\
\hline More interactive & 70.9 & 29.1 \\
\hline Easily searchable & 88.1 & 11.9 \\
\hline Updated information & 80.2 & 19.8 \\
\hline
\end{tabular}

Table 13. Positive aspects of using online resources

\begin{tabular}{|c|c|c|}
\hline $\begin{array}{c}\text { Negative Qualities of Online } \\
\text { Resources }\end{array}$ & \multicolumn{2}{|c|}{ Preference \% } \\
\hline & Yes & No \\
\hline Computer screen hard to read & 53.0 & 47.0 \\
\hline No time during faculty hours & 58.5 & 41.5 \\
\hline
\end{tabular}

Table 14. Negative aspects of using online resources

\begin{tabular}{|l|c|c|}
\hline & \multicolumn{2}{|c|}{ Yes \% No\% } \\
\hline Aware of faculty moodle platform? & 65.9 & 34.1 \\
\hline Using learning material in moodle? & 32.7 & 67.3 \\
\hline
\end{tabular}

Table 15. Exposure to the medical faculty moodle platform

\begin{tabular}{|l|c|c|}
\hline \multirow{2}{*}{$\begin{array}{l}\text { Functions used when using the Moodle } \\
\text { platform }\end{array}$} & \multicolumn{2}{|c|}{ Competency (\%) } \\
\cline { 2 - 3 } & Yes & No \\
\hline Upload text files & 46.9 & 53.1 \\
\hline Upload powerpoint presentations & 35.4 & 64.6 \\
\hline Upload images & 38.7 & 61.3 \\
\hline Upload Audio/Video files & 35.5 & 64.5 \\
\hline Insert links to other web pages & 40.0 & 60.0 \\
\hline Post in discussion forums & 50.0 & 50.0 \\
\hline Do quizzes/activities & 63.3 & 26.7 \\
\hline
\end{tabular}

Table 16. Competency of students who are currently using the Moodle platform 
Competency in using the Moodle platform was checked using the 31 students who were currently using it (Table 16). Out of the 138 students in the second year, only 31 were using the Moodle platform actively for their learning purposes. Out of that small sub population, the competency in using moodle was still poor, as more than $50 \%$ were not competent most of the time. Therefore, with the improvement of the content in the Moodle platform, there should be workshops to address issues on usage. This has been previously discussed briefly as a part of online educational methods, where the students requested training before the start of academic studies.

\begin{tabular}{|l|c|c|c|}
\hline & \multicolumn{3}{|c|}{ Preference \% } \\
\cline { 3 - 4 } $\begin{array}{c}\text { Supplementary Material to be } \\
\text { included in Moodle Platform }\end{array}$ & Positive & Neutral & Negative \\
\hline Lectures & 68.2 & 15.2 & 16.6 \\
\hline Tutorials & 66.7 & 15.2 & 18.1 \\
\hline Practicals & 76.1 & 10.8 & 13.1 \\
\hline Discussions & 67.9 & 16.0 & 16.1 \\
\hline
\end{tabular}

Table 17. Preferences on supplementary material for the Moodle platform

The breakdown of students' preferences to have supplementary material enriching the current teaching-learning strategies available in the faculty is as follows are in Table 17. About $94.7 \%$ of the students stated that they would like supplementary learning materials to be made available through the Faculty Moodle platform. More than two-thirds of the students wanted to see the incorporation of supplementary material for all five methods of face to face learning that was currently being practiced in the Faculty of Medicine available in the Faculty Moodle platform. This shows that there is a need for supplementary material in all aspects of the curriculum, from a student's point of view.

\section{Discussion}

When comparing results of this study conducted on the available ICT facilities, computer literacy and attitude towards e-learning among second year medical students at the Faculty of Medicine, University of Colombo with similar studies conducted in India $^{(11)}$ and Austria ${ }^{(12)}$, finding such as 93.5\% Sri Lankan students own a computer is similar to that of Indian and Austrian counterparts. However a higher rate of them seems have access to internet $(95 \%)$ than Indians $(86 \%)$ and is nearly similar to the Austrians (97\%). Competency in Microsoft Office applications was significantly higher $(>80 \%)$ than that of Indians. Use of online communication tools such as email was also high among Sri Lankan students (73.5\%) but lower than Austrians (94\%).

However, in the current situation, many medical students do not use the available IT devices for learning purposes. The majority of female students used internet to access social networks (eg. Facebook), while male students in addition were using blogs and twitter. The main types of 
supplementary material accessed by the students via the internet were text from Wikipedia, journals and web sites. Students have acknowledged the usefulness of online learning material.

With the Moodle platform in the Colombo Medical Faculty still being developed, awareness among students may not be high. This will be increased with the completion of development of the resources for Moodle. Majority of medical students stated that they would like supplementary learning material to be made available through the faculty Moodle platform. Majority of them also have recommended that supplementary material be added for lectures, tutorials, practicals, discussions and case studies. The current level of competence among medical students in using the Moodle platform is very weak. Teaching medical students to be computer-literate will not only enable them to use information technology competently, but will foster their capacity for "termless learning" which involves the ability to assess the adequacy of one's knowledge, to efficiently restore identified deficiencies ${ }^{(13)}$,

\section{Conclusion}

Results of this study conclude that medical students in Sri Lanka have access to computers and other facilities required for e-learning and also a positive attitude. However, their use of computers for learning purposes is low which necessitates guidance on the use of available resources for e-learning.

\section{References}

1. Romanov K, Nevgi A. Do medical students watch video clips in eLearning and do these facilitate learning? Medical Teacher. 2007; 29(5): 490-94

doi: http://dx.doi.org/10.1080/01421590701542119

2. Tavangarian D, Leypold $\mathrm{M}$, Nölting $\mathrm{K}$, et al. Is eLearning the Solution for Individual Learning? Electronic Journal of eLearning, 2004; 2: 273-80

doi: http://dx.doi.org/10.1.1.116.8017

3. Ward JPT, Gordon J, Field MJ. et al, Communication and information technology in medical education. Lancet 2001; 357: 792-96

doi: http://dx.doi.org/10.1016/S0140-6736(00)04173

4. Harden RM. Not just hype--the International Virtual Medical School (IVIMEDS)--a model of medical education for the future. Rays 2004; 29: 69-75

5. Kim S. The Future of eLearning in Medical Education: Current Trend and Future Opportunity. Journal of Educational Evaluation of Health Professions. 2006; 3: 3-5 doi: http://dx.doi.org/10.3352/jeehp.2006.3.3 
6. “What is Moodle?", [Online] 2010 Oct 10, [cited 2011 August 05]; Available from URL: http://moodle.org/mod/page/view.php?id=7736

7. Ruiz JG, Mintzer MJ, Leipzig RM. The Impact of E-Learning in Medical Education. Academic Medicine 2006; 81: 207-12

8. Trochim WMK. Likert Scaling 2006 Accessed on 5 August 2011. Available from : http://www.socialresearchmethods.net/kb/scallik.php

9. O'reilly T. What is Web 2.0? 2005 Accessed on 5 August 2011. Available from: http://oreilly.com/web2/archive/what-is-web-20.html

10. Wiecha J, Heyden R, Sternthal E. et al, Learning in a Virtual World: Experience With Using Second Life for Medical Education. Journal of Medical Internet Research. 2010; 12(1): e1. doi: http://dx.doi.org/10.2196/jmir.1337

11. Jha P, Paul L, Ojha P, et al. The Use of Computer by Medical Students in Chennai, India. 2003. Accessed on 5 August 2011. Available from: www.medindia.net/ articles/computer_using_medical_students7.asp

12. Link TM, Marz R. Computer literacy and attitudes towards eLearning among first year medical students. BMC Medical Education 2006; 6: 34-35

doi: http://dx.doi.org/10.1186/1472-6920-6-34

13. Koschmann T. Medical education and computer literacy: learning about, through, and with computers. Academic Medicine 1995; 70: 818-21 